\title{
Pathogenesis of occupational asthma
}

\author{
J. Sastre*, O. Vandenplas", H-S. Park
}

\begin{abstract}
Pathogenesis of occupational asthma. J. Sastre, O. Vandenplas, H-S. Park. (C)ERS Journals Ltd 2003.

ABSTRACT: The development of occupational asthma (OA) is likely to result from the complex interaction of environmental and host factors. This article addresses a series of issues relating to the multiple environmental factors that could affect the initiation of $\mathrm{OA}$, including the intrinsic characteristics of causative agents, as well as the influence of the level, mode and route of exposure.

Although the clinical and pathological features of $\mathrm{OA}$ caused by low molecular weight agents resemble those of immunoglobulin (Ig)E-mediated asthma, the failure to detect specific IgE antibodies against most of these agents and/or poor association with disease status have resulted in intense speculation about alternative or complementary physiopathological mechanisms leading to airway sensitisation.

In this contribution, the roles of specific immunoglobulin $E$ and $G$ antibodies, cellmediated immunity and inflammatory effector cells are critically reviewed. Recent advances in the characterisation of the molecular interactions between chemical sensitisers and human airway proteins provide promising avenues for elucidating the immunological basis of occupational asthma caused by low molecular weight agents. Eur Respir J 2003; 22: 364-373.
\end{abstract}

*Servicio de Alergia, Fundación Jiménez Díaz, Universidad Autónoma de Madrid, Madrid, Spain. " Service de Pneumologie, Cliniques de Mont-Godinne, Université catholique de Louvain, Yvoir, Belgium. "Dept of Allergy and Clinical Immunology, Ajou University School of Medicine, Suwon, Korea.

Correspondence: J. Sastre, Fundación Jiménez Díaz, Servicio de Alergia, Av Reyes Católicos 2, 28040 Madrid, Spain.

Fax: 34915499498

E-mail: jsastre@fjd.es

Keywords: Asthma, eosinophils, immunoglobulin E, immunoglobulin G, leukocytes, occupational disease

Received: April 222003

Accepted: April 282003
There is a general agreement that inhalation of agents at the workplace can induce the development of "immunological" as well as "nonimmunological" asthma [1-3]. The former, which will hereafter be conveniently referred to as occupational asthma (OA), arises after a latency period of exposure that is necessary for acquiring immunological sensitisation (whatever the underlying immunological mechanism), and asthma reactions recur on re-exposure to the causal agent at concentrations not affecting other similarly exposed workers. These clinical features of "allergic hypersensitivity" [4, 5] differentiate OA that is characterised by the presence of specific bronchial hyperresponsiveness to occupational agents, from nonimmunological asthma resulting from acute exposure(s) to high concentrations of irritants, often labelled "reactive airways dysfunction syndrome" or "irritant-induced asthma".

Extensive lists of the several hundreds of agents causing OA have been published [6-8] and are available on websites. These agents are somewhat arbitrarily, though conveniently, categorised into high molecular weight (HMW) and low molecular weight (LMW) agents according to whether their molecular weight is above or below $1 \mathrm{kD}$. HMW agents are (glyco)proteins from animal and vegetal origin acting through an immunological immunoglobulin (Ig)E-mediated mechanism. LMW agents include a wide variety of organic and inorganic compounds for which an IgE-mediated mechanism has not been consistently identified, although some of them (namely acid anhydrides, platinum salts and reactive dyes) are usually associated with the production of specific IgE antibodies.
This article will first examine the current understanding of the environmental factors that determine the inception of immunological OA in the perspective of focusing on recent advances and unresolved questions. Secondly, it will address a series of challenging issues pertaining to the pathophysiological mechanisms involved in the development of OA.

\section{Environmental determinants of occupational asthma}

The development of OA results from a complex interaction between environmental factors and individual susceptibility. The latter is specifically addressed in a separate contribution to this series [9]. Environmental factors that are potentially involved in the initiation of OA include the intrinsic characteristics of occupational agents, as well as the level, mode, and route of exposure at the workplace.

\section{Nature of the causative agent}

High molecular weight agents. In recent years, molecular cloning and modelling techniques have generated several hypotheses regarding the structural and functional characteristics of protein allergens that could determine their intrinsic potential for eliciting IgE-mediated sensitisation [10, 11]. Theoretically, structural features, biological activity, and mimicry with human proteins could be involved in protein

Previous articles in this series: No. 1: Vandenplas O, Malo J-L. Definitions and types of work-related asthma: a nosological approach. Eur Respir $J$ 2003; 21: 706-712. No. 2: Moscato G, Malo J-L, Bernstein D. Diagnosing occupational asthma: how, how much, how far? Eur Respir J 2003; 21 : 879-885. No. 3: Mapp CE. The role of genetic factors in occupational asthma. Eur Respir J 2003; 22: 173-178. 
allergenicity. To date, however, three-dimensional analysis of allergens has failed to characterise common molecular moieties that induce immunological sensitisation or to identify structural features that differentiate allergenic from nonallergenic proteins. In contrast to common inhalant allergens, resistance to degradation may be important for some occupational allergens, which may be altered by physical or chemical agents during industrial or manufacturing processes. This is best illustrated by the persistence of allergenic epitopes derived from Hevea braziliensis in natural rubber latex despite treatment with ammonia and vulcanisation at $100-120^{\circ} \mathrm{C}$ [12]. Conversely, a number of studies have raised the hypothesis that biological activity of allergens could contribute to their allergenicity.

Allergens have diverse biological functions, including enzymatic activities, enzyme inhibition, ligand binding, storage, plant defence against pathogens, and structural proteins. Most characterised allergens in mammalians are ligand-binding proteins (i.e. lipocalins or calycins), including allergens from cat (Fel d3), dog (Can f1, Can f2), cockroach (Bla g4), mouse (Mus m1), rat (Rat n1), cow (Bos d2, Bos d5 or $\beta$-lactoglobulin), and horse (Equ c1, Equ c2). Despite low amino acid homology, these proteins show the same characteristic lipocalin folding that can bind small hydrophobic molecules, such as pheromones, steroids and retinoids. There is growing evidence that enzymatic activity may potentiate allergenicity by facilitating transepithelial allergen delivery through disruption of tight junctions [13] and by stimulating IgE [14]. These data could support the observation that enzymes are a common cause of OA in a wide variety of occupations, for instance in detergent powder manufacture (e.g. alcalase, esperase) [15] or in the baking industry (e.g. fungal $\alpha$-amylase) [16]. In addition, among the few allergens that have been characterised in plant-derived products causing OA, a substantial number show enzymatic activity, such as the polyisoprene elongation factor (Hev b1) and $\beta$-1,3-glucanase (Hev b2) in natural rubber latex [12] or acyl-coenzyme A oxidase and fructose-biphosphate aldolase in cereal flour [17]. Nevertheless, enzymatic activity is not a prerequisite for allergenicity, since both enzyme inhibitors (e.g. $\beta$-amylase inhibitors in wheat flour, soybean trypsin inhibitor) and inactive enzymes (e.g. Bla g2, an inactive aspartate proteinase) can be potent allergens [11, 17, 18]. Finally, partial molecular homology of some allergens with human proteins could alter the mechanisms of self-tolerance. For instance, some endogenous lipocalins, such as retinolbinding protein, apolipoprotein D, and von Ebner's gland salivary protein, are homologous to exogenous lipocalin allergens. Although attractive, this hypothesis has not yet been formally substantiated.

Low molecular weight agents. In contrast to protein allergens, LMW agents are incomplete antigens (i.e. haptens) that must bind to carrier macromolecules to become immunogenic. Although new LMW agents are continuously recognised as inducing OA, only a minority of the thousands of LMW agents used in modern industry have demonstrated asthmagenic potency. It has long been recognised that LMW agents causing OA are typically highly reactive electrophilic compounds that are capable of combining with hydroxyl, amino and thiol functionalities on airway proteins [19]. Quantitative structure/ activity relationship models have recently contributed to further characterising the structural and physicochemical properties that determine the potential for inducing respiratory sensitisation [20-22]. These characteristics include the capacity to form at least two bonds with human proteins [21] and the agent's potential for chemical binding, as reflected by Hansen polarity and hydrogen-bond acceptance [22]. These models have identified a number of "structure alerts" that are associated with a high risk of respiratory sensitisation, including the isocyanate functionality $(\mathrm{N}=\mathrm{C}=\mathrm{O})$, primary and secondary amines, substituted aromatic moieties, dicarboxylic acid anhydrides, and dialdehydes [20, 21].

KAROL [23] has dedicated great effort to identifying the sites and target macromolecules of LMW agents adduction. In vitro experiments indicate that diisocyanates colocalise to ciliary tubulin in human lung epithelial cell lines [24] and react predominantly with keratin 18, actin, trans1,2-dihydrobenzene-1,2-diol dehydrogenase, and a 78-kD glucose-regulated protein involved in the trafficking of damaged proteins $[25,26]$. Following in vivo exposure of human subjects, the predominant diisocyanate-conjugated protein is keratin 18 in bronchial biopsies and albumin in bronchoalveolar lavage fluid [26]. Importantly, these experiments have shown that diisocyanate-conjugated epithelial proteins stimulate the proliferation of peripheral blood mononuclear cells (PBMCs) from subjects with diisocyanateinduced $\mathrm{OA}$ but not those from nonasthmatic subjects occupationally exposed to isocyanates nor those from subjects with atopic asthma of nonoccupational origin [25]. In vitro experiments have also demonstrated that diisocyanates combine with intracellular glutathione [27, 28]. The thiol adducts can be transferred to other nucleophilic proteins, suggesting the possibility of regeneration of the reactive chemicals at sites distant from the initial reaction through a "thiol shuttling" mechanism [27].

GRIFFIN et al. [29] have recently developed a monoclonal antibody that detects trimellitic anhydride irrespective of the carrier protein. In vitro incubation of this monoclonal antibody with a lung epithelial cell line revealed that trimellitic anhydride binds to $\geqslant 10$ proteins with molecular weights ranging $20-35 \mathrm{kD}$. It is likely that the development of such hapten-specific monoclonal antibodies would greatly enhance the understanding of the complex interactions between LMW reactive chemicals and lung proteins, and that it would enable the identification of antigenic determinants involved in the pathogenesis of OA caused by these agents.

\section{Level of exposure}

There is now compelling evidence of a dose/response relationship between the level of exposure to occupational agents and the development of IgE-mediated sensitisation and/or work-related respiratory symptoms for agents acting through an IgE-mediated mechanism, such as flour, fungal $\alpha$-amylase, laboratory animal proteins, detergent enzymes, platinum salts and acid anhydrides [30, 31]. The recognition of this relationship has been greatly enhanced by the development of immunoassay techniques for measurement of airborne allergens and by the implementation of prospective cohort studies [32-34]. An exposure/response gradient has also been substantiated indirectly for OA caused by diisocyanates $[35,36]$, although there is some suggestion that peak exposures could be more relevant for the initiation of diisocyanate-induced OA than for the cumulative dose of exposure [37].

Epidemiological studies have demonstrated that the level of exposure is the most important determinant of OA and, by implication, that preventive measures aimed at reducing workplace exposure to sensitising agents should be the most effective approach for reducing the burden of OA. For most occupational agents, however, the shape of exposure/response relationships remains largely uncertain. More specifically, little is known regarding the risk of sensitisation at low concentrations and the existence of a "no-effect level" [38]. 
Available information indicates that IgE-mediated sensitisation is unlikely to occur at concentrations $<0.5 \mathrm{mg} \cdot \mathrm{m}^{-3}$ for flour dust [38-40], $0.25 \mathrm{ng} \cdot \mathrm{m}^{-3}$ for fungal $\alpha$-amylase allergens [16], $0.7 \mu \mathrm{g} \cdot \mathrm{m}^{-3}$ for urinary rat allergens [32], and $0.6 \mathrm{ng} \cdot \mathrm{m}^{-3}$ for natural rubber latex allergens [41]. However, application of these data for setting occupational exposure standards is still hampered by the lack of standardisation of immunoassay techniques for quantitative assessment of airborne protein allergens. The opposite part of the dose/response curve may also be contentious. Thus, there is some evidence among laboratory animal workers that those with the highest exposure to rat urinary allergens have a lower risk of developing IgE-mediated sensitisation [33]. These findings are consistent with what has been described for domestic exposure to pets, particularly among young children [42]. This apparent protective effect of high-level exposure could result from high-dose immunological tolerance to allergens associated with a modified T-helper type-2 (Th2) cell response [43].

Exposure/response relationships may also be affected by individual susceptibility and timing of exposure. Genetic susceptibility markers seem to be stronger determinants of sensitisation to occupational agents at low levels of exposure to occupational agents [44], while the effect of atopy is independent from exposure level [33]. The incidence of immunological sensitisation and work-related symptoms is consistently higher within the early period of exposure to occupational agents [33, 45-47], and exposure/response gradients are more clearly documented in those workers who develop these outcomes soon after the onset of exposure $[33,48]$. These findings indicate that the level of exposure at critical time points may be more relevant to the development of OA than cumulative doses of exposure or current levels of exposure at the time of investigation.

\section{Mode of exposure}

Differences in the mode of exposure to the same HMW agent may result in different patterns of $\operatorname{IgE}$ responses. In asthma epidemics caused by soybean dust released during soybean unloading into harbour silos, citizens became sensitised to Gly $\mathrm{m} 1$ and Gly $\mathrm{m} 2$, which are proteins with an LMW (7-8 kD) concentrated in the hull, while bakers are sensitised predominantly to allergens with a HMW that are present both in soybean hull and flour [49]. It has also been reported that workers may develop specific airway reactivity directed against one but not the other forms of an LMW chemical (e.g. vapours of isocyanate monomers versus aerosols of isocyanates prepolymers, formaldehyde resin dust versus gaseous formaldehyde) [50, 51]. However, the extent to which physicochemical properties of occupational agents, such as size and solubility, may influence the pattern of airway deposition and, consequently, the potential for inducing airway sensitisation has not been investigated extensively.

There is accumulating evidence that environmental pollutants, such as ozone, sulphur dioxide, tobacco smoke and diesel exhaust particles, can potentiate immune responses to common inhalant allergens. Animal and human experiments have shown that respiratory irritants can enhance allergic airway inflammation and pre-existing $\mathrm{IgE}$ response to allergens in the human respiratory tract [52]. In addition, recent studies indicate that irritant substances are able to promote the initiation of IgE-mediated sensitisation to allergens [53-55]. The mechanisms of these interactions require further investigation, and may involve modified antigen presentation with skewing of cytokine production toward a Th2-like pattern.
To date, there is limited information on the potential interactions between irritant and sensitising agents at the workplace. Experiments in a primate model of asthma have suggested that exposure to ozone can potentiate the development of skin and bronchial responsiveness to hexachloroplatinate [56]. An association between cigarette smoking and an increased prevalence of sensitisation has been consistently documented only for platinum salts [57-59]. The effects of workplace exposure to irritant substances on the inception of airway sensitisation to occupational agents is undoubtedly a fascinating area of investigation that could have important implications in the field of prevention.

\section{Nonrespiratory routes of exposure}

Intuitively, inhalation is the most relevant route of exposure for the inception and maintenance of airway sensitisation to occupational agents. Nevertheless, recent animal experiments support the theory that skin exposure can initiate IgE-mediated respiratory sensitisation to allergens $[60,61]$. Epicutaneous application of a protein antigen (i.e. ovalbumin) induces a predominant Th2-like immune response with production of specific IgE antibodies, as well as the accumulation of eosinophils in bronchoalveolar lavage and the development of airway hyperresponsiveness (AHR) to methacholine after inhalation challenge with ovalbumin [62]. Animal models of sensitisation have consistently documented that dermal exposure to LMW agents, such as isocyanates and acid anhydrides, can lead to a specific IgE-antibody response and airway responses, and, in certain species, to the production of a Th2 profile of cytokines [63-66].

Much less is known about the potential impact of skin exposure on the initiation of $\mathrm{OA}$ in humans. Skin involvement, either urticaria or allergic contact dermatitis, when it is associated with OA, most often precedes the onset of asthma symptoms [67-69]. However, the effects of dermal contact cannot be easily differentiated from those of inhalation exposure as both occur simultaneously. The recent identification of type-1 keratins conjugated to hexamethylene diisocyanate (HDI) after both inhalation exposure to aerosolised HDI and skin exposure to liquid HDI in humans offers new insights into the link between skin sensitisation to LMW chemicals and the induction of AHR to these agents in animal models [26]. The possible interaction between dermal and respiratory exposures at the workplace should be further explored, as it may have practical implications for the implementation of preventive procedures.

\section{Physiopathological mechanisms leading to occupational asthma}

Athough it is clear that OA induced by HMW agents is mediated through a classical IgE-dependent hypersensitivity mechanism, there is no such general consensus regarding $\mathrm{OA}$ caused by LMW agents. For some LMW agents, notably acid anhydrides [70], platinum salts [71, 72], and reactive dyes [73, 74], the development of OA is accompanied by the production of specific IgE antibodies, while for most other LMW agents the presence of specific IgE has been documented in only a small subset of affected workers. The absence of detectable specific IgE antibodies directed against LMW agents has led to intense speculation about IgE-independent immunological or even nonimmunological mechanisms. 
Table 1.-Determination of specific immunoglobulin (Ig)E and IgG antibodies in subjects with occupational asthma caused by diisocyanates: comparison with the results of specific inhalation challenges

\begin{tabular}{|c|c|c|c|c|c|c|c|}
\hline \multirow[t]{2}{*}{ First author [ref.] } & \multirow[t]{2}{*}{ Type of diisocyanates } & \multirow[t]{2}{*}{$\begin{array}{c}\text { Subjects with } \\
\text { DOA/subjects tested }\end{array}$} & \multirow[t]{2}{*}{ Assay $^{\#}$} & \multicolumn{2}{|c|}{$\underset{\%}{\text { Specific } \operatorname{IgE}}$} & \multicolumn{2}{|c|}{$\underset{\%}{\text { Specific } \operatorname{IgG}}$} \\
\hline & & & & Se. & Sp. & Se. & Sp. \\
\hline BUTCHER [75] & TDI & $26 / 26$ & RAST & 19 & & & \\
\hline ZAMMIT-TABONA [76] & MDI & $6 / 11$ & RAST & 17 & 80 & 34 & 60 \\
\hline PEZZINI [77] & TDI, MDI, HDI & $28 / 28$ & RAST & 39 & & & \\
\hline KESKINEN [78] & TDI, MDI, HDI & $35 / 35$ & RAST & 20 & & & \\
\hline CARTIER [79] & TDI, MDI, HDI & $29 / 62$ & ELISA & 31 & 97 & 72 & 76 \\
\hline KAROL [80] & TDI & $34 / 63$ & RAST & 3 & 93 & 3 & 93 \\
\hline \multirow[t]{2}{*}{ TEE [81] } & TDI, MDI, HDI & $46 / 70$ & RAST ratio $>2$ & 28 & 92 & & \\
\hline & & & RAST ratio $>3$ & 20 & 100 & & \\
\hline PARK [82] & TDI & $50 / 63$ & ELISA & 14 & 92 & 46 & 92 \\
\hline BERNSTEIN [83] & TDI, MDI, HDI & $19 / 54$ & ELISA & 21 & 89 & 47 & 74 \\
\hline
\end{tabular}

DOA: diisocyanate-induced occupational asthma as ascertained by specific inhalation challenge; Se.: sensitivity; Sp.: specificity; HDI: hexamethylene diisocyanate; MDI: diphenylmethane diisocyanate; TDI: toluene diisocyanate. \#: specific IgE antibodies binding to diisocyanates conjugated to human serum albumin have been assessed using either radioallergosorbent test (RAST) or enzyme-linked immunosorbent assay (ELISA), while specific IgG antibodies were determined using ELISA technique.

\section{Specific immunoglobulin E antibodies}

Binding of specific IgE antibodies to hapten conjugated with human serum albumin (HSA) has been reported in a low proportion of workers with ascertained OA caused by most LMW agents, including diisocyanates (0-39\%) [75-83] (table 1), plicatic acid derived from western red cedar (44\%) [84], glutaraldehyde (31\%) [85] and cobalt $(50 \%)$ [86]. The presence of specific IgE antibodies to LMW agents conjugates generally shows a very high specificity for OA (table 1), although they can be found in asymptomatic exposed workers $[87,88]$. Interestingly, a recent follow-up study of workers exposed to trimellitic anhydride showed that specific $\operatorname{IgE}$ antibodies may precede the development of OA [89].

The absence of demonstrable specific IgE antibodies in subjects with OA caused by LMW agents could result from a number of methodological limitations. Indeed, the innate chemical reactivity of most LMW agents has largely hampered the investigation of immunological mechanisms, owing to uncertainty about the antigens that elicit immunological responses. It has been assumed that LMW agents act as haptens that are presented to the human immune system after conjugation with carrier proteins. The interaction of LMW reactive agents with human proteins may produce immunogenic epitopes that are related both to the LMW agent itself and to new antigenic determinants resulting from conformational changes of the carrier protein. It has been shown that assessment of specific IgE antibodies directed against LMW agents conjugated to HSA is affected by the conditions used for preparing hapten conjugates [90, 91]. The sensitivity in detecting specific IgE against LMW agents may be affected by the interval between assessment and last workplace exposure. The levels of specific IgE against LMW agents decline after cessation of workplace exposure with half-life estimates ranging from 6 months to 4 yrs for diisocyanatespecific IgE antibodies [81, 92]. Most importantly, immunological studies have to date focused on the antigenicity of LMW agents conjugated to HSA, however, it is now established that LMW chemicals can combine with a variety of airway proteins $[25,26,29]$. Accordingly, the role of specific antibodies needs to be re-examined using LMW agents conjugated to human proteins other than HSA, such as epithelial cell proteins, which may represent more biologically relevant antigens.

Finally, it should be considered that if OA caused by LMW agents results from IgE-dependent mechanisms in a small subset of affected subjects and from IgE-independent mechanisms in the other subjects, it would be reasonable to expect differences in clinical manifestations between these two subsets. To date, studies have failed to identify differences in the pattern of asthmatic reactions or other clinical features between subjects with and without IgE, with the slight exception that the presence of specific IgE against diisocyanates could be associated with a less severe outcome [93].

\section{Specific immunoglobulin $G$ antibodies}

A number of studies have reported that $\operatorname{IgG}$ antibodies against diisocyanate-HSA conjugates are more sensitive, though less specific, than IgE antibodies in identifying OA when compared with the results of specific inhalation challenges (table 1) [76, 79, 82, 83]. High levels of specific IgG to diisocyanates at the time of diagnosis have been associated with a more severe outcome of asthma in a 5-yr follow-up study of workers with OA caused by toluene diisocyanate [94]. These findings, however, cannot be regarded as definitive evidence supporting a pathogenetic role of IgG antibodies in OA due to LMW agents. Indeed, most workforce surveys have found that the presence of specific $\mathrm{IgG}$ antibodies is associated with the level of exposure rather than with work-related respiratory symptoms among workers exposed to diisocyanates [88, 95-97] and acid anhydrides $[98,99]$. Specific $\mathrm{IgG}_{4}$ antibodies directed against LMW agents have been assessed by several investigators who found that the presence of this class of antibodies reflects exposure alone and is not associated with the presence of work-related respiratory symptoms [87, 99]. Only one study [98] has documented an association between the presence of specific $\mathrm{IgG}_{4}$ against phthalic anhydride and work-related asthma, while specific IgG antibodies correlated with the level of workplace exposure. Investigation of specific IgG and $\mathrm{IgG}_{4}$ in workers exposed to HMW agents provided broadly similar results, since the levels of these antibodies correlated with estimates of exposure to rat allergens [100], wheat flour [101] and grain dust [102], but not with the presence of workrelated symptoms. There was an association between specific $\mathrm{IgG}$ and/or $\mathrm{IgG}_{4}$ antibodies and specific IgE among workers exposed to reactive dyes [103], citrus red mite [104] and grain dust [102]. 
These data are consistent with those reported in asthma caused by common inhalant allergens. Specific IgG antibodies to common allergens (e.g. dust-mite allergens) usually correlate with the level of exposure and are most often associated with specific IgE antibodies [43, 105]. The presence of specific IgG antibodies in the absence of $\operatorname{IgE}$ antibodies may, however, be found when there is a strong antigenic stimulus, such as that associated with high-level exposure to cat allergens in children or with immunotherapy [43, 105], where $\mathrm{IgG}$ and $\mathrm{IgG}_{4}$ could play a protective effect. Taken collectively, available data do not indicate that $\mathrm{IgG}$ antibodies play a significant role, either offending or protective, in the pathogenesis of OA caused by LMW agents.

\section{Cell-mediated immunity}

Several lines of evidence indicate that T-cells are involved in the pathogenesis of OA caused by LMW. In animal experiments, sensitisation to diisocynates can be transferred by injection of lymphoid cells [106], while AHR and pathology changes do not develop in athymic mice [107]. Studies of workers with diisocyanate-induced OA have found that the expression of $\mathrm{V} \beta 1$ and $\mathrm{V} \beta 5$ gene segment is decreased at baseline in PBMCs and increases selectively after in vitro incubation with diisocyanate-HSA conjugates [108]. These findings suggest that antigen-specific T-cell subpopulations may be sequestred in the lungs of workers with diisocyanate-induced $\mathrm{OA}$ and clonally expand after exposure to the causative agent. Upon in vitro stimulation by diisocyanate-HSA conjugates, PBMCs from workers with diisocyanate-induced OA show a proliferative response $[25,108]$, although hapten-specific proliferative responses of PBMCs are inconsistently detected in subjects with OA caused by LMW agents [109, 110], are also found in asymptomatic exposed workers [88], and are absent in OA caused by LMW agents other than isocyanates, such as plicatic acid from red cedar [111]. In addition, when haptenspecific proliferative response is present, its magnitude is significantly smaller than that induced by common inhalant allergens [108]. In vitro experiments have also reported that PBMCs of workers with diisocyanate-induced OA demonstrate a hapten-specific production of histamine-releasing factor $[112,113]$ and the release of monocyte chemoattractant protein-1, interleukin (IL)-8, tumour necrosis factor (TNF)- $\alpha$, and interferon (IFN)- $\gamma$ [114]. However, it remains to be established whether LMW agents are capable of inducing a direct, IgE-independent, hapten-specific activation of PBMCs.

Bronchial biopsy specimens from subjects with atopic asthma, nonatopic asthma, and OA caused by LMW agents show a broadly similar pattern of inflammatory cell infiltrate in the airways, including mast cells, eosinophils and activated lymphocytes [115-118]. Immunopathological studies of workers with diisocyanate-induced OA have, however, revealed several features suggesting that different physiopathological processes could be involved. Most T-lymphocyte clones derived from bronchial biopsies of atopic asthmatics are CD4+ with a Th2 pattern of cytokine production, while in diisocynate-induced OA, the majority of lymphocytes represent CD8+ T-cells [119] and fail to demonstrate a definite pattern of Th1 or Th2 cytokine profiles. T-cell clones derived from bronchial mucosa of subjects with OA caused by LMW agents produce IL-5 and IFN- $\gamma$, but not IL-4 [119-121], although the number of cells expressing IL-4 and IL-5 increases after in vivo exposure to diisocyanates [120]. These somewhat disappointing findings should, however, be examined in light of the increasingly accepted concept that the pattern of cytokine production by human T-cells is more heterogeneous than that found in mice. It is now becoming apparent that CD8+ T-cells may participate in the process of asthma and exhibit Th1 and Th2 phenotypes, with the Th2 phenotype producing IL-5 or both IFN- $\gamma$ and IL-5 $[122,123]$.

Findings in animal models of sensitisation to LMW agents are affected by the sensitisation and challenge protocols. In a mouse model of sensitisation through subcutaneous injection of toluene diisocyanate, TNF- $\alpha$ appeared to play a pivotal role in the production of $\mathrm{Th} 2$ cytokines in airway tissues, independently from specific antibody levels [107, 124]. Dermal sensitisation to toluene diisocyanate in mice resulted in the production of Th1-type IFN- $\gamma$ and Th2-type cytokines (IL-4, -5 and -13 ), although only Th2 cytokines were important for the development of airway eosinophilia. These results were in contrast to the markedly Th2-skewed cytokine profile induced by protein allergens, such as ovalbumin [65]. Using a mouse model of dermal sensitisation, DEARMAN and KIMBER [64] have shown that LMW agents causing OA in humans (i.e. acid anhydrides, diisocyanates and platinum salts) are associated with selective Th2 responses characterised by the production of IL-4 and IL-10 by draining lymph-node cells. By contrast, chemicals causing only allergic contact dermatitis induce a predominant Th1 pattern of cytokines associated with high levels of IFN- $\gamma$.

\section{Nonimmunological mechanisms}

In vitro experiments have shown that diisocyanates, and presumably other reactive LMW agents, have a variety of pro-inflammatory effects. Diisocyanates can induce intracellular glutathione deficiency [27, 28], which may induce the activation of mitogen-activated protein kinase and the production of RANTES (regulated on activation, T-cell expressed and secreted) [125]. Exposure to diisocyanates is associated with increased levels of intracellular peroxide and the expression of intercellular adhesion molecule- 1 in monocytic cell lines [126]. The production of reactive oxygen species could contribute to tissue damage, and the upregulation of adhesion markers on monocytic cells could potentiate the infiltration and adhesion of inflammatory cells at the site of exposure to diisocyanates [126]. It has also been shown that diisocyanates can exert a bronchoconstricting effect on bronchial smooth muscle and trigger neurogenic inflammation through the activation of the efferent function of capsaicin-sensitive sensory nerves and the inhibition of neutral endopeptidase [127, 128]. These effects have, however, been documented only in experimental models using high concentrations of diisocyanates. The relevance of these mechanisms in the pathogenesis of $\mathrm{OA}$ can be questioned, since they cannot account for the clinical manifestations of "allergic hypersensitivity" [4, 5] that are characteristic features of this condition. Nevertheless, it is conceivable that nonimmunological mechansims could play an indirect role in the development of $\mathrm{OA}$ by amplifying immunological responses to LMW agents, especially in susceptible individuals [129, 130].

\section{Airway inflammation}

It is almost universally accepted that eosinophils represent central inflammatory effector cells involved in the development of the AHR and variable airflow obstruction that characterise asthma [122]. However, investigations of bronchoalveolar lavage and induced sputum in subjects with OA have provided more controversial findings. Some of these studies have reported increased numbers of eosinophils at baseline 
[131] with a further increase after exposure to various causative agents at work [132] or in the laboratory [133-136]. Other studies have described an increase in neutrophil chemotactic activity associated with recruitment and activation of neutrophils during asthmatic reactions provoked by diisocyanates [137-139]. Neutrophilic inflammation with concomitant changes in AHR has also been reported in one subject exposed to metal working fluids at the workplace [140]. In addtion, DI FRANCO et al. [141] found more neutrophils and fewer eosinophils in the sputum of subjects with OA caused by LMW agents than in that of subjects with HMW agent-induced OA or non-OA. LEMIÈRE et al. [142] documented increases in both eosinophils and neutrophils in sputum after asthmatic reactions induced by LMW and HMW agents, and these cellular changes occurred independently from the temporal pattern of asthmatic reactions. Sputum neutrophilia, however, was observed more frequently after challenge exposure to diisocyanates, even at very low concentrations [143]. A recent study by ANEES et al. [144] suggested that OA caused by LMW agents could be differentiated into eosinophilic and noneosinophilic variants, with the latter predominating, although both groups had sputum neutrophilia. Eosinophilic inflammation was associated with a greater severity of the disease and a greater bronchodilator reversibility but not with the magnitude of work-related changes in peak expiratory flow rates. In this study, one-half of the subjects diagnosed as having "noneosinophilic OA" failed to demonstrate significant AHR to methacholine, suggesting that the noneosinophilic variant of OA may be related, at least in part, to a nonspecific "irritant" effect. Indeed, neutrophilic airway inflammation can be triggered, even in nonasthmatic subjects, by a variety of environmental exposures, including bacterial endotoxins, particulate air pollution and ozone.

Collectively, these findings indicate that neutrophils are involved in OA, perhaps more frequently, but not exclusively, when OA is provoked by LMW agents. These data appear to contrast with the "eosinophilic dogma" in asthma. However, a recent review has also questioned the central role of eosinophils in non-OA by outlining that $\sim 50 \%$ of asthmatics in the general population fail to show eosinophilic airway inflammation [145]. Interestingly, noneosinophilic asthma is most often associated with increased numbers of neutrophils and high IL-8 levels. Such a neutrophilic inflammation occurs not only in severe asthma or during asthma exacerbations but also in mild and moderate asthma, as well as after inhalation challenges with common inhalant allergens. Thus, neutrophils appear to be involved in the pathophysiology of asthma, both in occupational settings and in the general population, and their role should be further delineated.

In recent years, eosinophilic inflammation of the airways has been increasingly recognised as a cause of chronic cough without demonstrable nonspecific AHR or airflow obstruction [146]. To date, two reports of eosinophilic bronchitis causally related to the workplace environment have been published $[147,148]$. In one case, specific inhalation challenge showed that cyanoacrylate was the causative agent [147]. In the other case, chronic cough and sputum eosinophilia were related to latex sensitisation [148]. After treatment with inhaled steroids and latex avoidance, the cough markedly improved and eosinophils were no longer observed in sputum samples. Inhalation challenge test with latex reproduced the cough and sputum eosinophilia. Although the pathophysiological mechanisms and long-term implications of "occupational eosinophilic bronchitis" need to be clarified further, this entity should be considered as a variant form of OA [3].

\section{Conclusions and perspectives}

Understanding the pathogenesis of OA is a crucial step toward optimal prevention and management of the condition. In this respect, identifying the structural and biological characteristics that determine the potential for inducing airway sensitisation is fundamental to the implementation of primary preventive strategies. A body of epidemiological evidence has accumulated to support a dose/response relationship between the level of exposure to HMW agents and the development of OA, although application of this information to the determination of exposure limits in the workplace will require the standardisation of assessment methods. Further research is needed to clarify the impact of nonrespiratory routes of exposure and concomitant exposure to pollutants in the workplace.

The pathogenesis of occupational asthma caused by low molecular weight agents remains largely uncertain, since the innate chemical reactivity of these agents has obscured the investigation of immunological mechanisms. Available data suggest that T-cell subset and cytokine profile involved in occupational asthma caused by low molecular weight agents may differ from those operating in atopic asthma. At present, however, there is little direct evidence that immunoglobulin E-independent immunological or nonimmunological mechanisms alone are able to account for the initiation and perpetuation of occupational asthma. Recent advances in the characterisation of the molecular interactions between low molecular weight agents should lead to a re-exploration of the nature of immunological mechanisms using more biologically relevant antigenic determinants.

Acknowledgements. The authors would like to thank L. Schubert for reviewing the manuscript.

\section{References}

1. Chan-Yeung M. Assessment of asthma in the workplace. ACCP consensus statement. Ameican College of Chest Physicians. Chest 1995; 108: 1084-1117.

2. Bernstein IL, Bernstein DI, Chan-Yeung M, Malo JL. Definition and classification of asthma. In: Bernstein IL, Chan-Yeung M, Malo JL, Bernstein DI, eds. Asthma in the Workplace. 2nd Edn. New York, Marcel Dekker Inc., 1999; pp. 1-3.

3. Vandenplas O, Malo JL. Definitions and types of workrelated asthma: a nosological approach. Eur Respir $J$ 2003; 21: 706-712.

4. Newman Taylor AJ. Occupational asthma. Thorax 1980; 35: 241-245.

5. Johansson $\mathrm{SG}$, Hourihane $\mathrm{JO}$, Bousquet $\mathrm{J}$, et al. A revised nomenclature for allergy. An EAACI position statement from the EAACI nomenclature task force. Allergy 2001; 56: 813-824.

6. Chan-Yeung M, Malo JL. Aetiological agents in occupational asthma. Eur Respir J 1994; 7: 346-371.

7. Chan-Yeung M, Malo JL. Tables of major inducers of occupational asthma. In: Bernstein IL, Chan-Yeung $\mathrm{M}$, Malo JL, Bernstein DI, eds. Asthma in the Workplace. 2nd Edn. New York, Marcel Dekker Inc., 1999; pp. 683-720.

8. van Kampen V, Merget R, Baur X. Occupational airway sensitizers: an overview on the respective literature. Am J Ind Med 2000; 38: 164-218.

9. Mapp CE. The genetic susceptibility to occupational asthma. Eur Respir J 2003; 22: 173-178.

10. Aalberse RC. Structural biology of allergens. J Allergy Clin Immunol 2000; 106: 228-238.

11. Pomes A. Intrinsic properties of allergens and environmental 
exposure as determinants of allergenicity. Allergy 2002; 57: 673-679.

12. Sussman GL, Beezhold DH, Kurup VP. Allergens and natural rubber proteins. J Allergy Clin Immunol 2002; 110: S33-S39.

13. Wan H, Winton HL, Soeller C, et al. Der p 1 facilitates transepithelial allergen delivery by disruption of tight junctions. J Clin Invest 1999; 104: 123-133.

14. Ghaemmaghami AM, Gough L, Sewell HF, Shakib F. The proteolytic activity of the major dust mite allergen Der $\mathrm{p} 1$ conditions dendritic cells to produce less interleukin-12: allergen-induced Th2 bias determined at the dendritic cell level. Clin Exp Allergy 2002; 32: 1468-1475.

15. Cullinan P, Harris JM, Newman Taylor AJ, et al. An outbreak of asthma in a modern detergent factory. Lancet 2000; 356: 1899-1900.

16. Houba R, Heederik DJ, Doekes G, van Run PE. Exposuresensitization relationship for alpha-amylase allergens in the baking industry. Am J Respir Crit Care Med 1996; 154: 130 136.

17. Baur X, Posch A. Characterized allergens causing bakers' asthma. Allergy 1998; 53: 562-566.

18. Quirce S, Fernandez-Nieto M, Polo F, Sastre J. Soybean trypsin inhibitor is an occupational inhalant allergen. J Allergy Clin Immunol 2002; 109: 178.

19. Agius RM, Nee J, McGovern B, Robertson A. Structure activity hypotheses in occupational asthma caused by low molecular weight substances. Ann Occup Hyg 1991; 35: 129 137.

20. Graham C, Rosenkranz HS, Karol MH. Structure-activity model of chemicals that cause human respiratory sensitization. Regul Toxicol Pharmacol 1997; 26: 296-306.

21. Agius RM. Why are some low-molecular-weight agents asthmagenic. Occup Med 2000; 15: 369-384.

22. Karol MH, Macina OT, Cunningham A. Cell and molecular biology of chemical allergy. Ann Allergy Asthma Immunol 2001; 87: 28-32.

23. Karol MH. Bonding and transfer: do epithelial conjugates have a role in chemical asthma? Clin Exp Allergy 2001; 31: $357-360$

24. Lange RW, Lantz RC, Stolz DB, et al. Toluene diisocyanate colocalizes with tubulin on cilia of differentiated human airway epithelial cells. Toxicol Sci 1999; 50: 64-71.

25. Wisnewski AV, Lemus $\mathrm{R}$, Karol MH, Redlich CA. Isocyanate-conjugated human lung epithelial cell proteins: A link between exposure and asthma? J Allergy Clin Immunol 1999; 104: 341-347.

26. Wisnewski AV, Srivastava R, Herick C, et al. Identification of human lung and skin proteins conjugated with hexamethylene diisocyanate in vitro and in vivo. Am J Respir Crit Care Med 2000; 162: 2330-2336.

27. Day BW, Jin R, Basalyga DM, Kramarik JA, Karol MH. Formation, solvolysis, and transcarbamoylation reactions of bis(S-glutathionyl) adducts of 2,4- and 2,6-diisocyanatotoluene. Chem Res Toxicol 1997; 10: 424-431.

28. Lantz RC, Lemus R, Lange RW, Karol MH. Rapid reduction of intracellular glutathione in human bronchial epithelial cells exposed to occupational levels of toluene diisocyanate. Toxicol Sci 2001; 60: 348-355.

29. Griffin P, Allan L, Beckett P, Elms J, Curran AD. The development of an antibody to trimellitic anhydride. Clin Exp Allergy 2001; 31: 453-457.

30. Heederik D, Thorne PS, Doekes G. Health-based occupational exposure limits for high molecular weight sensitizers: how long is the road we must travel? Ann Occup Hyg 2002; 46: 439-446.

31. Newman Taylor A. Asthma and Work: The Colt Lecture, delivered at the Ninth International Symposium on Inhaled Particles, Cambridge, September 2001. Ann Occup Hyg 2002; 46: $563-574$.

32. Cullinan P, Lowson D, Nieuwenhuijsen MJ, et al. Work related symptoms, sensitisation, and estimated exposure in workers not previously exposed to laboratory rats. Occup Environ Med 1994; 51: 589-592.

33. Cullinan P, Cook A, Gordon S, et al. Allergen exposure, atopy and smoking as determinants of allergy to rats in a cohort of laboratory employees. Eur Respir J 1999; 13: 11391143 .

34. Gautrin D, Ghezzo H, Infante-Rivard C, Malo JL. Incidence and determinants of IgE-mediated sensitization in apprentices. A prospective study. Am J Respir Crit Care Med 2000; 162: $1222-1228$.

35. Tarlo SM, Liss GM, Dias C, Banks DE. Assessment of the relationship between isocyanate exposure levels and occupational asthma. Am J Ind Med 1997; 32: 517-521.

36. Meredith SK, Bugler J, Clark RL. Isocyanate exposure and occupational asthma: a case-referent study. Occup Environ Med 2000; 57: 830-836.

37. Leroyer C, Perfetti L, Cartier A, Malo JL. Can reactive airways dysfunction syndrome (RADS) transform into occupational asthma due to "sensitisation" to isocyanates? Thorax 1998; 53: 152-153.

38. Heederik D, Houba R. An exploratory quantitative risk assessment for high molecular weight sensitizers: wheat flour. Ann Occup Hyg 2001; 45: 175-185.

39. Cullinan P, Lowson D, Nieuwenhuijsen MJ, et al. Work related symptoms, sensitisation, and estimated exposure in workers not previously exposed to flour. Occup Environ Med 1994; 51: 579-583.

40. Houba R, van Run P, Heederik D, Doekes G. Wheat antigen exposure assessment for epidemiological studies in bakeries using personal dust sampling and inhibition ELISA. Clin Exp Allergy 1996; 26: 154-163.

41. Baur X, Chen Z, Allmers H. Can a threshold limit value for natural rubber latex airborne allergens be defined? J Allergy Clin Immunol 1998; 101: 24-27.

42. Apelberg BJ, Aoki Y, Jaakkola JJ. Systematic review: Exposure to pets and risk of asthma and asthma-like symptoms. J Allergy Clin Immunol 2001; 107: 455-460.

43. Platts-Mills T, Vaughan J, Squillace S, Woodfolk J, Sporik R. Sensitisation, asthma, and a modified Th2 response in children exposed to cat allergen: a population-based crosssectional study. Lancet 2001; 357: 752-756.

44. Newman Taylor AJ, Cullinan P, Lympany PA, Harris JM, Dowdeswell RJ, du Bois RM. Interaction of HLA phenotype and exposure intensity in sensitization to complex platinum salts. Am J Respir Crit Care Med 1999; 160: 435-438.

45. Juniper CP, How MJ, Goodwin BF, Kinshott AK. Bacillus subtilis enzymes: a 7-year clinical, epidemiological and immunological study of an industrial allergen. J Soc Occup Med 1977; 27: 3-12.

46. Botham PA, Lamb CT, Teasdale EL, Bonner SM, Tomenson JA. Allergy to laboratory animals: a follow up study of its incidence and of the influence of atopy and pre-existing sensitisation on its development. Occup Environ Med 1995; 52: 129-133.

47. Gautrin D, Ghezzo H, Infante-Rivard C, Malo JL. Natural history of sensitization, symptoms and occupational diseases in apprentices exposed to laboratory animals. Eur Respir $J$ 2001; 17: 904-908

48. Hollander A, Heederik D, Doekes G. Respiratory allergy to rats: exposure-response relationships in laboratory animal workers. Am J Respir Crit Care Med 1997; 155: 562-567.

49. Quirce S, Polo F, Figueredo E, Gonzalez R, Sastre J. Occupational asthma caused by soybean flour in bakersdifferences with soybean-induced epidemic asthma. Clin Exp Allergy 2000; 30: 839-846.

50. Vandenplas $\mathrm{O}$, Cartier A, Lesage $\mathrm{J}$, et al. 1 Prepolymers of hexamethylene diisocyanate as a cause of occupational asthma. J Allergy Clin Immunol 1993; 91: 850-861.

51. Lemiere C, Desjardins A, Cloutier Y, et al. Occupational asthma due to formaldehyde resin dust with and without reaction to formaldehyde gas. Eur Respir J 1995; 8: 861865. 
52. Jenkins HS, Devalia JL, Mister RL, Bevan AM, Rusznak C, Davies RJ. The effect of exposure to ozone and nitrogen dioxide on the airway response of atopic asthmatics to inhaled allergen: dose- and time-dependent effects. $\mathrm{Am}$ J Respir Crit Care Med 1999; 160: 33-39.

53. Miyabara Y, Takano H, Ichinose T, Lim HB, Sagai M. Diesel exhaust enhances allergic airway inflammation and hyperresponsiveness in mice. Am J Respir Crit Care Med 1998; 157: 1138-1144.

54. Diaz-Sanchez D, Garcia MP, Wang M, Jyrala M, Saxon A. Nasal challenge with diesel exhaust particles can induce sensitization to a neoallergen in the human mucosa. $J$ Allergy Clin Immunol 1999; 104: 1183-1188.

55. Rumold R, Jyrala M, Diaz-Sanchez D. Secondhand smoke induces allergic sensitization in mice. J Immunol 2001; 167: 4765-4770.

56. Biagini RE, Moorman WJ, Lewis TR, Bernstein IL. Ozone enhancement of platinum asthma in a primate model. $\mathrm{Am}$ Rev Respir Dis 1986; 134: 719-725.

57. Venables KM, Dally MB, Nunn AJ, et al. Smoking and occupational allergy in workers in a platinum refinery. $B M J$ 1989; 299: 939-942.

58. Calverley AE, Rees D, Dowdeswell RJ, Linnett PJ, Kielkowski D. Platinum salt sensitivity in refinery workers: incidence and effects of smoking and exposure. Occup Environ Med 1995; 52: 661-666.

59. Merget R, Kulzer R, Dierkes-Globisch A, et al. Exposureeffect relationship of platinum salt allergy in a catalyst production plant: conclusions from a 5-year prospective cohort study. J Allergy Clin Immunol 2000; 105: 364-370.

60. Beck LA, Leung DY. Allergen sensitization through the skin induces systemic allergic responses. J Allergy Clin Immunol 2000; 106: S258-S263.

61. Saloga J, Knop J. Does sensitization through the skin occur? Allergy 2000; 55: 905-909.

62. Spergel JM, Mizoguchi E, Brewer JP, Martin TR, Bhan AK, Geha RS. Epicutaneous sensitization with protein antigen induces localized allergic dermatitis and hyperresponsiveness to methacholine after single exposure to aerosolized antigen in mice. J Clin Invest 1998; 101: 1614-1622.

63. Sarlo K, Karol MH. Animal models of occupational asthma. In: Bernstein IL, Chan-Yeung M, Malo JL, Bernstein DI, eds. Asthma in the Workplace. 2nd Edn. New York, Marcel Dekker Inc., 1999; pp. 111-127.

64. Dearman RJ, Kimber I. Cytokine fingerprinting and hazard assessment of chemical respiratory allergy. J Appl Toxicol 2001; 21: 153-163.

65. Herrick CA, Xu L, Wisnewski AV, Das J, Redlich CA, Bottomly K. A novel mouse model of diisocyanate-induced asthma showing allergic-type inflammation in the lung after inhaled antigen challenge. J Allergy Clin Immunol 2002; 109: 873-878.

66. Redlich CA, Wisnewski AV, Gordon T. Mouse models of diisocyanate asthma. Am J Respir Cell Mol Biol 2002; 27: 385-390.

67. Vandenplas $\mathrm{O}$, Charous $\mathrm{BL}$, Tarlo S. Latex allergy. In: Bernstein IL, Chan-Yeung M, Malo JL, Bernstein DI, eds. Asthma in the Workplace. 2nd Edn. New York: Marcel Dekker Inc., 1999; pp. 425-444.

68. Kanerva L, Keskinen H, Autio P, Estlander T, Tuppurainen M, Jolanki R. Occupational respiratory and skin sensitization caused by polyfunctional aziridine hardener. Clin Exp Allergy 1995; 25: 432-439.

69. De Raeve H, Vandecasteele C, Demedts M, Nemery B. Dermal and respiratory sensitization to chromate in a cement floorer. Am J Ind Med 1998; 34: 169-176.

70. Zeiss CR, Patterson R, Venables KM. Acid anhydrides. In: Bernstein IL, Chan-Yeung M, Malo JL, Bernstein DI, eds. Asthma in the Workplace. 2nd Edn. New York, Marcel Dekker Inc., 1999; pp. 479-500.

71. Murdoch RD, Pepys J, Hughes EG. IgE antibody responses to platinum group metals: a large scale refinery survey. $\mathrm{Br}$ $J$ Ind Med 1986; 43: 37-43.

72. Merget R, Schultze-Werninghaus G, Bode F, Bergmann EM, Zachgo W, Meier-Sydow J. Quantitative skin prick and bronchial provocation tests with platinum salt. $\mathrm{Br} J$ Ind Med 1991; 48: 830-837.

73. Park HS, Lee MK, Kim BO, et al. Clinical and immunologic evaluations of reactive dye-exposed workers. J Allergy Clin Immunol 1991; 87: 639-649.

74. Park JW, Kim CW, Kim KS, et al. Role of skin prick test and serological measurement of specific IgE in the diagnosis of occupational asthma resulting from exposure to vinyl sulphone reactive dyes. Occup Environ Med 2001; 58: 411-416.

75. Butcher BT, O'Neil CE, Reed MA, Salvaggio JE. Radioallergosorbent testing of toluene diisocyanate-reactive individuals using p-tolyl isocyanate antigen. $J$ Allergy Clin Immunol 1980; 66: 213-216.

76. Zammit-Tabona M, Sherkin M, Kijek K, Chan H, ChanYeung M. Asthma caused by diphenylmethane diisocyanate in foundry workers. Clinical, bronchial provocation, and immunologic studies. Am Rev Respir Dis 1983; 128: 226-230.

77. Pezzini A, Riviera A, Paggiaro $\mathrm{P}$, et al. Specific IgE antibodies in twenty-eight workers with diisocyanateinduced bronchial asthma. Clin Allergy 1984; 14: 453-461.

78. Keskinen H, Tupasela O, Tiikkainen U, Nordman H. Experiences of specific IgE in asthma due to diisocyanates. Clin Allergy 1988; 18: 597-604.

79. Cartier A, Grammer L, Malo JL, et al. Specific serum antibodies against isocyanates: association with occupational asthma. J Allergy Clin Immunol 1989; 84: 507-514.

80. Karol MH, Tollerud DJ, Campbell TP, et al. Predictive value of airways hyperresponsiveness and circulating $\mathrm{IgE}$ for identifying types of responses to toluene diisocyanate inhalation challenge. Am J Respir Crit Care Med 1994; 149: 611-615.

81. Tee RD, Cullinan P, Welch J, Burge PS, Newman-Taylor AJ. Specific IgE to isocyanates: a useful diagnostic role in occupational asthma. J Allergy Clin Immunol 1998; 101: 709715

82. Park HS, Kim HY, Nahm DH, Son JW, Kim YY. Specific $\mathrm{IgG}$, but not specific IgE, antibodies to toluene diisocyanatehuman serum albumin conjugate are associated with toluene diisocyanate bronchoprovocation test results. J Allergy Clin Immunol 1999; 104: 847-851.

83. Bernstein DI, Cartier A, Cote J, et al. Diisocyanate antigenstimulated monocyte chemoattractant protein-1 synthesis has greater test efficiency than specific antibodies for identification of diisocyanate asthma. Am J Respir Crit Care Med 2002; 166: 445-450.

84. Tse KS, Chan H, Chan-Yeung M. Specific IgE antibodies in workers with occupational asthma due to western red cedar. Clin Allergy 1982; 12: 249-258.

85. Curran AD, Burge PS, Wiley K. Clinical and immunologic evaluation of workers exposed to glutaraldehyde. Allergy 1996; 51: 826-832.

86. Shirakawa T, Kusaka Y, Fujimura N, et al. Occupational asthma from cobalt sensitivity in workers exposed to hard metal dust. Chest 1989; 95: 29-37.

87. Yokota K, Yamaguchi K, Takeshita T, Morimoto K. The significance of specific IgG4 antibodies to methyltetrahydrophthalic anhydride in occupationally exposed subjects. Clin Exp Allergy 1998; 28: 694-701.

88. Redlich CA, Stowe MH, Wisnewski AV, et al. Subclinical immunologic and physiologic responses in hexamethylene diisocyanate-exposed auto body shop workers. Am $J$ Ind Med 2001; 39: 587-597.

89. Grammer L, Shaughnessy M, Kenamore B. Utility of antibody in identifying individuals who have or will develop anhydride-induced respiratory disease. Chest 1998; 114: 1199-1202.

90. Hong CS, Park HS. Heterogeneity of IgE antibody response 
to reactive dye in sera from four different sensitized workers Clin Exp Allergy 1992; 22: 606-610.

91. Park HS, Kim HY, Lee SK, Kim SS, Nahm DH. Diverse profiles of specific IgE response to toluene diisocyanate (TDI)- human serum albumin conjugate in TDI-induced asthma patients. J Korean Med Sci 2001; 16: 57-61.

92. Park HS, Lee SK, Lee YM, Kim SS, Nahm DH. Longitudinal study of specific antibodies to toluene diisocyanate (TDI)-human serum albumin (HSA) conjugate in patients with TDI-induced asthma. Korean J Intern Med 2002; 17: 249-251.

93. Piirila PL, Nordman H, Keskinen HM, et al. Long-term follow-up of hexamethylene diisocyanate-, diphenylmethane diisocyanate-, and toluene diisocyanate-induced asthma. $\mathrm{Am}$ J Respir Crit Care Med 2000; 162: 516-522.

94. Park HS, Lee SK, Kim HY, Nahm DH, Kim SS. Specific immunoglobulin $\mathrm{E}$ and immunoglobulin $\mathrm{G}$ antibodies to toluene diisocyanate-human serum albumin conjugate: useful markers for predicting long-term prognosis in toluene diisocyanate-induced asthma. Clin Exp Allergy 2002; 32: 551-555.

95. Liss GM, Bernstein DI, Moller DR, Gallagher JS, Stephenson RL, Bernstein IL. Pulmonary and immunologic evaluation of foundry workers exposed to methylene diphenyldiisocyanate (MDI). J Allergy Clin Immunol 1988; 82: 55-61.

96. Welinder H, Nielsen J, Bensryd I, Skerfving S. IgG antibodies against polyisocyanates in car painters. Clin Allergy 1988; 18: 85-93.

97. Lushniak BD, Reh CM, Bernstein DI, Gallagher JS. Indirect assessment of 4,4'-diphenylmethane diisocyanate (MDI) exposure by evaluation of specific humoral immune responses to MDI conjugated to human serum albumin. Am J Ind Med 1998; 33: 471-477.

98. Nielsen J, Welinder H, Schutz A, Skerfving S. Specific serum antibodies against phthalic anhydride in occupationally exposed subjects. J Allergy Clin Immunol 1988; 82: 126-133.

99. Welinder H, Nielsen J, Gustavsson C, Bensryd I, Skerfving S. Specific antibodies to methyltetrahydrophthalic anhydride in exposed workers. Clin Exp Allergy 1990; 20: 639-645.

100. Platts-Mills TA, Longbottom J, Edwards J, Cockroft A, Wilkins S. Occupational asthma and rhinitis related to laboratory rats: serum $\mathrm{IgG}$ and $\mathrm{IgE}$ antibodies to the rat urinary allergen. J Allergy Clin Immunol 1987; 79: 505-515.

101. Tiikkainen U, Klockars M. Clinical significance of IgG subclass antibodies to wheat flour antigens in bakers. Allergy 1990; 45: 497-504.

102. Park HS, Suh $\mathrm{CH}, \mathrm{Nahm}$ DH, Kim HY. Presence of specific IgG antibody to grain dust does not go with respiratory symptoms. J Korean Med Sci 1999; 14: 39-44.

103. Park HS, Hong CS. The significance of specific IgG and IgG4 antibodies to a reactive dye in exposed workers. Clin Exp Allergy 1991; 21: 357-362.

104. Park HS, Kim HY, Kim YK, et al. Specific IgG1 and IgG4 antibodies to citrus red mite in citrus farmers: a study of their relationship to respiratory symptoms. J Korean Med Sci 2000; 15: 407-412.

105. Aalberse RC. Specific IgE and IgG responses in atopic versus nonatopic subjects. Am J Respir Crit Care Med 2000; 162: S124-S127.

106. Scheerens H, Buckley TL, Davidse EM, Garssen J, Nijkamp $\mathrm{FP}$, van Loveren $\mathrm{H}$. Toluene diisocyanate-induced in vitro tracheal hyperreactivity in the mouse. Am J Respir Crit Care Med 1996; 154: 858-865.

107. Matheson JM, Lemus R, Lange RW, Karol MH, Luster MI. Role of tumor necrosis factor in toluene diisocyanate asthma. Am J Respir Cell Mol Biol 2002; 27: 396-405.

108. Bernstein JA, Munson J, Lummus ZL, Balakrishnan K, Leikauf $\mathrm{G}$. T-cell receptor $\mathrm{V}$ beta gene segment expression in diisocyanate-induced occupational asthma. J Allergy Clin Immunol 1997; 99: 245-250.

109. Kusaka Y, Nakano Y, Shirakawa T, Morimoto K.
Lymphocyte transformation with cobalt in hard metal asthma. Ind Health 1989; 27: 155-163.

110. Lee M, Park S, Park HS, Youn JK. Cytokine secretion patterns of $\mathrm{T}$ cells responding to haptenized-human serum albumin in toluene diisocyanate (TDI)-induced asthma patients. J Korean Med Sci 1998; 13: 459-465.

111. Frew AJ, Chan H, Chan-Yeung M. Lack of role for mononuclear cell-derived histamine releasing factors in occupational asthma due to western red cedar. Clin Exp Allergy 1993; 23: 861-867.

112. Herd ZL, Bernstein DI. Antigen-specific stimulation of histamine releasing factors in diisocyanate-induced occupational asthma. Am J Respir Crit Care Med 1994; 150: 988994.

113. Lummus ZL, Alam R, Bernstein JA, Bernstein DI. Characterization of histamine releasing factors in diisocyanateinduced occupational asthma. Toxicology 1996; 111: 191-206.

114. Lummus ZL, Alam R, Bernstein JA, Bernstein DI. Diisocyanate antigen-enhanced production of monocyte chemoattractant protein-1, IL-8, and tumor necrosis factoralpha by peripheral mononuclear cells of workers with occupational asthma. J Allergy Clin Immunol 1998; 102: 265274.

115. Saetta M, Di Stefano A, Maestrelli P, et al. Airway mucosal inflammation in occupational asthma induced by toluene diisocyanate. Am Rev Respir Dis 1992; 145: 160-168.

116. Bentley AM, Maestrelli P, Saetta M, et al. Activated T-lymphocytes and eosinophils in the bronchial mucosa in isocyanate-induced asthma. J Allergy Clin Immunol 1992; 89: 821-829.

117. Boulet LP, Boutet $\mathrm{M}$, Laviolette $\mathrm{M}$, et al. Airway inflammation after removal from the causal agent in occupational asthma due to high and low molecular weight agents. Eur Respir J 1994; 7: 1567-1575.

118. Maestrelli P, di Stefano A, Occari $\mathrm{P}$, et al. Cytokines in the airway mucosa of subjects with asthma induced by toluene diisocyanate. Am J Respir Crit Care Med 1995; 151: 607-612.

119. Maestrelli P, Del Prete GF, De Carli M, et al. CD8 T-cell clones producing interleukin-5 and interferon-gamma in bronchial mucosa of patients with asthma induced by toluene diisocyanate. Scand J Work Environ Health 1994; 20: $376-381$.

120. Maestrelli P, Occari P, Turato G, et al. Expression of interleukin (IL)-4 and IL-5 proteins in asthma induced by toluene diisocyanate (TDI). Clin Exp Allergy 1997; 27: 12921298.

121. Frew A, Chang $\mathrm{JH}$, Chan $\mathrm{H}$, et al. T-lymphocyte responses to plicatic acid-human serum albumin conjugate in occupational asthma caused by western red cedar. J Allergy Clin Immunol 1998; 101: 841-847.

122. Lee NA, Gelfand EW, Lee JJ. Pulmonary $\mathrm{T}$ cells and eosinophils: coconspirators or independent triggers of allergic respiratory pathology? J Allergy Clin Immunol 2001; 107: 945-957.

123. Larche $\mathrm{M}$, Robinson DS, Kay $\mathrm{AB}$. The role of $\mathrm{T}$ lymphocytes in the pathogenesis of asthma. J Allergy Clin Immunol 2003; 111: 450-463.

124. Matheson JM, Lange RW, Lemus R, Karol MH, Luster MI. Importance of inflammatory and immune components in a mouse model of airway reactivity to toluene diisocyanate (TDI). Clin Exp Allergy 2001; 31: 1067-1076.

125. Hashimoto S, Gon Y, Matsumoto K, Takeshita I, MacHino $\mathrm{T}$, Horie $\mathrm{T}$. Intracellular glutathione regulates tumour necrosis factor-alpha-induced p38 MAP kinase activation and RANTES production by human bronchial epithelial cells. Clin Exp Allergy 2001; 31: 144-151.

126. Elms J, Beckett PN, Griffin P, Curran AD. Mechanisms of isocyanate sensitisation. An in vitro approach. Toxicol In Vitro 2001; 15: 631-634.

127. Scheerens H, Buckley TL, Muis T, van Loveren H, Nijkamp FP. The involvement of sensory neuropeptides in toluene 
diisocyanate-induced tracheal hyperreactivity in the mouse airways. Br J Pharmacol 1996; 119: 1665-1671.

128. Mapp CE, Lucchini RE, Miotto D, et al. Immunization and challenge with toluene diisocyanate decrease tachykinin and calcitonin gene-related peptide immunoreactivity in guinea pig central airways. Am J Respir Crit Care Med 1998; 158: 263-269.

129. Wikman H, Piirila P, Rosenberg C, et al. $N$-Acetyltransferase genotypes as modifiers of diisocyanate exposure-associated asthma risk. Pharmacogenetics 2002; 12: 227-233.

130. Piirila P, Wikman H, Luukkonen R, et al. Glutathione$S$-transferase genotypes and allergic responses to diisocyanate exposure. Pharmacogenetics 2001; 11: 437-445.

131. Chan-Yeung M, Obata H, Dittrick M, Chan H, Abboud R. Airway inflammation, exhaled nitric oxide, and severity of asthma in patients with western red cedar asthma. Am J Respir Crit Care Med 1999; 159: 1434-1438.

132. Lemiere C, Pizzichini MM, Balkissoon R, et al. Diagnosing occupational asthma: use of induced sputum. Eur Respir $J$ 1999; 13: 482-488.

133. Maestrelli P, Calcagni PG, Saetta M, Di, et al. Sputum eosinophilia after asthmatic responses induced by isocyanates in sensitized subjects. Clin Exp Allergy 1994; 24: 29-34.

134. Obata H, Dittrick M, Chan H, Chan-Yeung M. Sputum eosinophils and exhaled nitric oxide during late asthmatic reaction in patients with western red cedar asthma. Eur Respir J 1999; 13: 489-495.

135. Lemiere C, Chaboilliez S, Trudeau C, et al. Characterization of airway inflammation after repeated exposures to occupational agents. J Allergy Clin Immunol 2000; 106: 1163-1170.

136. Quirce S, Baeza ML, Tornero P, Blasco A, Barranco R, Sastre J. Occupational asthma caused by exposure to cyanoacrylate. Allergy 2001; 56: 446-449.

137. Fabbri LM, Boschetto P, Zocca E, et al. Bronchoalveolar neutrophilia during late asthmatic reactions induced by toluene diisocyanate. Am Rev Respir Dis 1987; 136: 36-42.

138. Sastre J, Banks DE, Lopez M, Barkman HW, Salvaggio JE.
Neutrophil chemotactic activity in toluene diisocyanate (TDI)-induced asthma. J Allergy Clin Immunol 1990; 85: 567-572.

139. Park HS, Jung KS, Kim HY, Nahm DH, Kang KR. Neutrophil activation following TDI bronchial challenges to the airway secretion from subjects with TDI-induced asthma. Clin Exp Allergy 1999; 29: 1395-1401.

140. Leigh R, Hargreave FE. Occupational neutrophilic asthma. Can Respir J 1999; 6: 194-196.

141. Di Franco A, Vagaggini B, Bacci E, et al. Leukocyte counts in hypertonic saline-induced sputum in subjects with occupational asthma. Respir Med 1998; 92: 550-557.

142. Lemière $\mathrm{C}$, Chaboillez $\mathrm{S}$, Malo JL, Cartier A. Changes in sputum cell counts after exposure to occupational agents: what do they mean? J Allergy Clin Immunol 2001; 107: $1063-$ 1068.

143. Lemière $\mathrm{C}$, Romeo $\mathrm{P}$, Chaboillez $\mathrm{S}$, Tremblay $\mathrm{C}$, Malo JL. Airway inflammation and functional changes after exposure to different concentrations of isocyanates. J Allergy Clin Immunol 2002; 110: 641-646.

144. Anees W, Huggins V, Pavord ID, Robertson AS, Burge PS. Occupational asthma due to low molecular weight agents: eosinophilic and non-eosinophilic variants. Thorax 2002; 57: 231-236.

145. Douwes J, Gibson P, Pekkanen J, Pearce N. Noneosinophilic asthma: importance and possible mechanisms. Thorax 2002; 57: 643-648.

146. Gibson PG, Fujimura M, Niimi A. Eosinophilic bronchitis: clinical manifestations and implications for treatment. Thorax 2002; 57: 178-182.

147. Lemière C, Efthimiadis A, Hargreave FE. Occupational eosinophilic bronchitis without asthma: an unknown occupational airway disease. J Allergy Clin Immunol 1997; 100: 852-853.

148. Quirce S, Fernandez-Nieto M, de Miguel J, Sastre J. Chronic cough due to latex-induced eosinophilic bronchitis. $J$ Allergy Clin Immunol 2001; 108: 143. 